\title{
The Global Rise of Eating Disorders and Mortality
}

\author{
Stephanie P Elko* \\ The Emily Program, USA
}

Submission: April 02, 2019; Published: April 10, 2019

*Corresponding author: Stephanie P Elko, The Emily Program, 2230 Como Ave, St. Paul, MN 55108, USA

\begin{abstract}
Eating disorder rates are increasing globally, including in both food secure and food insecure communities. The most recent research suggests this rise spans cultures and gender. This mini-review provides an overview of recent research on anorexia nervosa, recognition of symptoms and laboratory or procedures changes seen in a patient with anorexia nervosa malnutrition, approaches to intervention, and determination for a level of care.
\end{abstract}

Keywords: Eating disorders; Anorexia nervosa; Bulimia nervosa; Binge-eating disorder; Malnutrition; National Eating Disorder Association

\section{Introduction}

Eating disorders, specifically anorexia nervosa, bulimia nervosa, and binge-eating disorder, were once thought to be a disorder among the limited, specifically Western young Caucasian females, is now on the rise across cultures and countries. This is concerning for many reasons. The most notable being that eating disorders (ED), specifically anorexia nervosa, have the highest mortality among all mental health disorders, including suicide [1].

\section{Discussion}

In 2014, a review by Pike et al, found that ED rates are increasing with the increased industrialization, urbanization and globalization of Arab and Asian countries [2]. Following this, Hoek writes that China and India, in conjunction with the United States, have some of the highest disability adjusted life year contributions due to ED, likely due to their large populations [3]. Then in 2015 Pike et al, broadened their findings to note that not only was there an increase in locations across Asia, but also cultures and gender [4]. In conjunction with this a research, The National Eating Disorders Association noted that there was a $53 \%$ increase in the number of men hospitalized for ED from 1999 to 2009 [5]. Ideally continued research will be completed in both developed and developing contributes to create a more complete understanding of the global ED rise as countries continue to industrialize and modernize.

Now that we have this emerging data, where do we go from here? Ideally to improve recognition and intervention. Though this can be a challenging diagnosis to make as a clinician, given the often-secretive nature of the disorders. To better understand how to recognize and intervene, we must first understand how our bodies adapt to times of starvation.

\section{Eating Disorder Clinician Recognition}

Initially, the body may use its stored energy reserves. If the state is chronic, the body will go into a state of conservation of energy, which is why patients with chronic malnutrition from anorexia can tolerate marked bradycardia, hypotension, hypoglycemia. Some of these changes can be seen by trained clinicians with patient symptoms, physical exam and labs.

Whereas during times of BED the body can become obese, hypertensive and glucose dysregulated leading to diabetes and its associated co-morbidities.

\section{Intervention}

Once recognized, patients with EDs need direct access to an ED specialist or facility. There are multiple levels of care for these patients based on needs. The treatments types can range from inpatient hospitalizations, residential centers, partial hospitalization or intensive day programs, to outpatient services. Often these treatments include medical, psych, dietary and behavioral provider teams. Determination for a level of care for a patient is complicated and usually may even be a team approach with both a medical and psychological evaluation (Table 1). Although, there is no standard at which to hospitalize a patient for nutritional restoration and stabilization, there are suggested clinical practice guidelines surrounding it. Table 2 outlines these guidelines [6,7].

\section{Conclusion}

EDs are on the rise globally. Although our global access to food has improved, our relationship with food seems to have become even more complicated. Further research needs to be completed to truly understand the comprehensive picture 


\section{Global Journal of Archaeology \& Anthropology}

regarding the future of EDs. EDs pose a significant risk to patients and, potentially, their surrounding communities. People deadly. Lives will be saved if we, as clinicians, can recognize EDs must eat to survive and when you have an ED the outcome can be

Table 1: is a quick review table of some of the common symptoms, physical findings, and laboratory or procedures changes seen in a patient with anorexia nervosa malnutrition $[6,7]$.

\begin{tabular}{|c|c|c|}
\hline Symptoms & Physical Finding & Lab/Procedure Findings \\
\hline \multicolumn{3}{|l|}{ Exertional fatigue } \\
\hline \multicolumn{3}{|l|}{ Weakness } \\
\hline Cold intolerance & Digital cyanosis, hypothermia (core temperature $<35^{\circ} \mathrm{C}$ ) & \\
\hline Palpatipation & $\begin{array}{c}\text { Bradycardia (pulse }<60 \text { beats per minute), new onset } \\
\text { murmur (Mitral Valve Prolapse) }\end{array}$ & $\begin{array}{c}\text { ECG/EKG: bradycardia, low or negative T wave } \\
\text { on precordial leads }\end{array}$ \\
\hline Dizziness & $\begin{array}{c}\text { Hypotension (systolic blood pressure }<90 \mathrm{mmHG} \text { and/ } \\
\text { or diastolic blood pressure }<50 \mathrm{mmHg} \text { ), dehydration, } \\
\text { paroxysmal vital signs }\end{array}$ & Abnormal labs reflecting dehydration \\
\hline Abdominal pain and bloating & Hypoactive bowel sounds & $\begin{array}{l}\text { Gas build up in gastric lumen on abdominal } \\
\mathrm{x} \text {-ray to due to slowed transit/peristalsis }\end{array}$ \\
\hline Early satiety & Epigastric tenderness & Gastroparesis on gastric emptying study \\
\hline Constipation & Abdominal distension & Abdominal X-ray reveals constipation \\
\hline Swelling of feet & Pedal edema and periorbital & \\
\hline Skin and hair changes & $\begin{array}{l}\text { Xerosis (dry, scaly skin), brittle hair with or without hair loss, } \\
\text { lanugo hair growth, hypercarotenemia, }\end{array}$ & $\begin{array}{l}\text { DEXA scan reveals decreased bone density, } \\
\text { leukocytosis }\end{array}$ \\
\hline Irritability & Mood changes, lack of insight into body habitus & \\
\hline
\end{tabular}

Table 2: Suggested clinical practice guidelines surrounding eating disorder inpatient criteria [6,7].

\begin{tabular}{|c|c|}
\hline 1 & Bradycardia less than 40 beats per minute \\
\hline 2 & Hypotension with blood pressure less than $80 / 60 \mathrm{mmHg}$ or if symptomatic \\
\hline 3 & Cardiac dysrhythmia (ie, QTc $>0.499 \mathrm{msec}$ ), or any rhythm other than normal sinus or bradycardia \\
\hline 4 & $\begin{array}{c}\text { Weight }<70 \text { percent of ideal body weight, if for a female with amenorrhea) or a body mass index of less than } 14 \mathrm{~kg} / \mathrm{m}^{2} \text {, especially if rapid } \\
\text { weight loss }\end{array}$ \\
\hline 5 & Cardiovascular, hepatic or renal compromise requiring medical stabilizations \\
\hline 6 & $\begin{array}{l}\text { Noted serious medical complications of malnutrition (ie, syncope, seizures, marked dehydration, cardiac failure, marked electrolyte } \\
\text { disturbances, pancreatitis) }\end{array}$ \\
\hline 7 & Hypoglycemia, which has a poor prognosis \\
\hline 8 & Marked edema \\
\hline
\end{tabular}

\section{Acknowledgements}

The Emily Program.

\section{References}

1. Arcelus J, Mitchell AJ, Wales J, Nielsen S (2011) Mortality rates in patients with anorexia nervosa and other eating disorders. A meta-analysis of 36 studies. Arch Gen Psychiatry 68(7): 723-731.

2. Pike K, Hoek HW, Dunne PE (2014) Recent cultural trends and eating disorders. Curr Opin Psychiatry 27: 436-442.
3. Hoek HW (2016) Review of the worldwide epidemiology of eating disorders. Curr Opin Psychiatry p. 29

4. Pike KM, Dunne PE (2015) The rise of eating disorders in Asia: a review. J Eat Disord 3: 33

5. Statistics \& Research on Eating Disorders (2018).

6. Anorexia nervosa in adults (2019) Evaluation for medical complications and criteria for hospitalization to manage these complications.

7. Mehler PS, Andersen AE (2017) Eating disorders: a guide to medical care and complications. ( $3^{\text {rd }}$ edn), Johns Hopkins University Press, Baltimore, USA. 
(C) This work is licensed under Creative BY DOI: 10.19080/GJAA.2019.08.555745

\section{Your next submission with Juniper Publishers} will reach you the below assets

- Quality Editorial service

- Swift Peer Review

- Reprints availability

- E-prints Service

- Manuscript Podcast for convenient understanding

- Global attainment for your research

- Manuscript accessibility in different formats ( Pdf, E-pub, Full Text, Audio)

- Unceasing customer service

Track the below URL for one-step submission https://juniperpublishers.com/online-submission.php 